\title{
Cytology technique: development of a simple spot method for cultured cell suspension
}

\author{
Jeanne A. Pawitan, ${ }^{1}$ Lia Damayanti, ${ }^{1}$ Arleni,,${ }^{2,3}$ Ni M. Swantari ${ }^{4}$ \\ ${ }^{1}$ Department of Histology, Faculty of Medicine, University of Indonesia, Jakarta, Indonesia \\ ${ }^{2}$ Depatment of Biology, Faculty of Medicine, University of Indonesia, Jakarta, Indonesia \\ ${ }^{3}$ Immunology and Endocrinology Integrated Laboratory, Faculty of Medicine, University of Indonesia, Jakarta, Indonesia \\ ${ }^{4}$ Division of Plastic Surgery, Department of Surgery, Faculty of Medicine, University of Indonesia, Jakarta, Indonesia
}

\begin{abstract}
Abstrak
Tujuan Mengembangkan cara spot sederhana untuk melekatkan suspensi sel hasil kultur pada kaca objek.

Metode Kami membandingkan tiga cara, masing-masing pada kaca objek biasa dan khusus (Shandon-Polysin). Ketiga cara tersebut adalah membuat sediaan spot kecil secara langsung, atau dengan menambahkan 3 atau 10 pl fetal bovine serum (FBS) per $20 \mu \mathrm{l}$ sampel. Dengan demikian, secara keseluruhan ada 6 cara. Hasilnya dinilai secara kualitatif dalam hal warna latar belakang, warna dan keutuhan batas spot, dan bagian yang terlipat dan terlepas. Selanjutnya, untuk tiap kaca objek, jumlah sel utuh yang melekat dihitung, dan persentase sel utuh yang melekat per jumlah sel yang dibuat spot juga dihitung. Perbedaan sel utuh yang melekat di antara keenam cara di atas dianalisis dengan ANOVA menggunakan program SPSS 13.0 for Windows.
\end{abstract}

Hasil Tidak ada perbedaan bermakna di antara keenam cara di atas dalam hal persentase sel utuh yang melekat $(P=$ 0,804), walaupun cara yang menggunakan kaca objek khusus tanpa penambahan FBS (kadar FBS final 5\%) menghasilkan persentase sel utuh melekat yang paling tinggi, dengan latar belakang bersih tanpa lipatan.

Kesimpulan Kami telah mengembangkan cara spot sederhana untuk membuat sediaan sitologi suspensi sel hasil kultur, dan hasil terbaik didapat dengan menggunakan kaca objek khusus dengan suspensi sel berkadar FBS 5\%. (Med J Indones 2010; 19:26-31)

\begin{abstract}
Aim To develop a simple spot method to attach cultured cells in suspension on to a glass slide.

Methods We compared three approaches using both conventional and special glass slide (Shandon-Polysin)., either without additional fetal bovine serum (FBS), or with addition of 3 or $10 \mu 1$ of FBS to a $20 \mu 1$ sample (altogether there were six approaches). The slides were examined qualitatively for the background color, boundary color and intactness, and whether there were folded and detached parts. Further, for each slide, the attached intact cells were counted, and the percentage of attached intact cells per number of spotted cells was calculated. The difference in attach intact cells between different approaches was analyzed by ANOVA using SPSS 13.0 for windows.

Results There were no significant difference in the percentage of attached intact cells between the six approaches $(\mathrm{P}=$ 0.804), though the approach using special glass slide without additional FBS (FBS final concentration 5\%) yield the highest percentage of attached intact cells, showed clean background without folded parts.

Conclusions We have developed a simple spot method for cultured cell suspension, and the best approach to make spot specimen is using special glass slide with 5\% FBS in the cell suspension. (Med J Indones 2010; 19:26-31)
\end{abstract}

Key words: spot specimen, special glass slide, fetal bovine serum

Visualization of stained cultured cells is usually done by staining of either cultured cells on chamber slides, ${ }^{1,3}$ on coverslips, glass slide in culture dishes, or wells of tissue culture plates. ${ }^{4-7}$ These methods require an additional culture that need at least one day for culturing and additional culture medium. Moreover, when various kinds of staining are needed, the number of culture dishes, wells or chamber slide rises according to the number of staining method used, and thus will increase the cost.

Correspondence email to: jeanneadiwip@fk.ui.ac.id
Another method is by making cytology specimens from cultured cell suspension using a cytospin apparatus. ${ }^{8}$ This method needs a cytospin apparatus that is not always available in a basic laboratory. Further, the use of disposable cytospin chambers raises the cost, while using reusable chambers often leads to contamination, if the chambers are not washed thoroughly. ${ }^{9}$

To overcome such hurdles, we developed a simple spot method to attach cultured cells in suspension on to a glass slide, by comparing various spotting approaches. 


\section{METHODS}

This research is part of a research on adipose tissue derived stem cells, which has got an approval from the ethical committee of the Faculty of Medicine University of Indonesia. This research was done in the Immunology and Endocrinology Integrated Laboratory, and the Department of Histology, Faculty of Medicine, University of Indonesia, from October 2009 to January 2010.

\section{Sample and sample processing}

The samples were adipose tissue derived trypsinized cultured cell suspensions. The trypsin in the cell suspensions was neutralized by equal volume of culture medium containing $10 \%$ fetal bovine serum (FBS), Penicillin - Streptomycin and Amphotericin B in Dulbeco Minimal Eagle Medium (DMEM).

\section{Procedure of spot method}

The cells in cell suspensions were counted in Neubauer chamber, on an inverted microscope. Then 1-2 $\mu$ l of cells in aliquot samples were spotted on to clean glass slide, using a micro pipette and a yellow tip. If air bubbles developed, they were broken by a sewing needle. We tried various approaches i.e.: Approach-1: spotting the cell suspension directly on conventional glass slide; approach-2: spotting the cell suspension directly on special glass slide; approach-3: before spotting on to conventional glass slide, $20 \mu \mathrm{l}$ of cell suspension was mixed with 3 $\mu \mathrm{l}$ FBS; approach-4: before spotting on to special glass slide, $20 \mu \mathrm{l}$ of cell suspension was mixed with $3 \mu \mathrm{l} \mathrm{FBS}$; approach-5: before spotting on to conventional glass slide, $20 \mu 1$ of cell suspension was mixed with $10 \mu \mathrm{FBS}$; and approach- 6 before spotting on to special glass slide, $20 \mu \mathrm{l}$ of cell suspension was mixed with $10 \mu \mathrm{l}$ FBS

The spotted cell suspensions were air dried and fixed using 100\% ethyl alcohol (proanalysis, Merck) for 5 minutes, stained by hematoxylin and eosin (HE) staining, cleared in xylene (proanalysis, Merck), mounted in mounting medium (Entellan) and covered by a coverslip ( $22 \times 22 \mathrm{~mm}$, Assistent).

\section{HE staining procedure}

Before staining, the dried cell suspension were rehydrated using ethyl alcohol $70 \%, 50 \%$ and distilled water for 5 minutes each subsequently. Then the slides were immersed in hematoxylin solution for 1 minute, washed in running tap water, followed by 3 dips in $0.1 \mathrm{~N}$ HCL, several dips in distilled water, and immersed in eosin solution for 3 minutes. After that, the slides were washed in distilled water, followed by dehydration in $50 \%, 70 \%, 95 \%$, and $100 \%$ ethyl alcohol for 5 minutes each subsequently, dipped several times in xylene, and finally a drop of mounting medium was added on to the glass slide to cover the spot and covered by a coverslip.

Every approach was done in 5 replicates. The number of attached intact cells on each glass slide was counted under an ordinary light microscope, with 400 times of magnification. Cell counting was done on the whole spotted specimen.

Further the background was examined for its color, and the boundary was examined for the color and intactness. Our preliminary attempts to make spot specimens showed that the spotted cell suspension formed a thin layer when it was dried. In some of them, part of the thin layer was detached or folded. Therefore, in addition to the above examinations, the whole specimen was examined whether there were folded or detached parts, and they were qualitatively evaluated.

The background and boundary color was labeled -, +, ,+++++ when the color is clear, pale, lightly colored, or colored, respectively (Figure 1). Further, the same method of labeling was applied for the boundary intactness, and folded and detached parts, which were labeled according to the amount of intact boundary, amount of folded and detached parts, respectively.

Cell counting, examination of background color, boundary color and intactness, and evaluation of folded and detached part was done blinded by one examiner. 


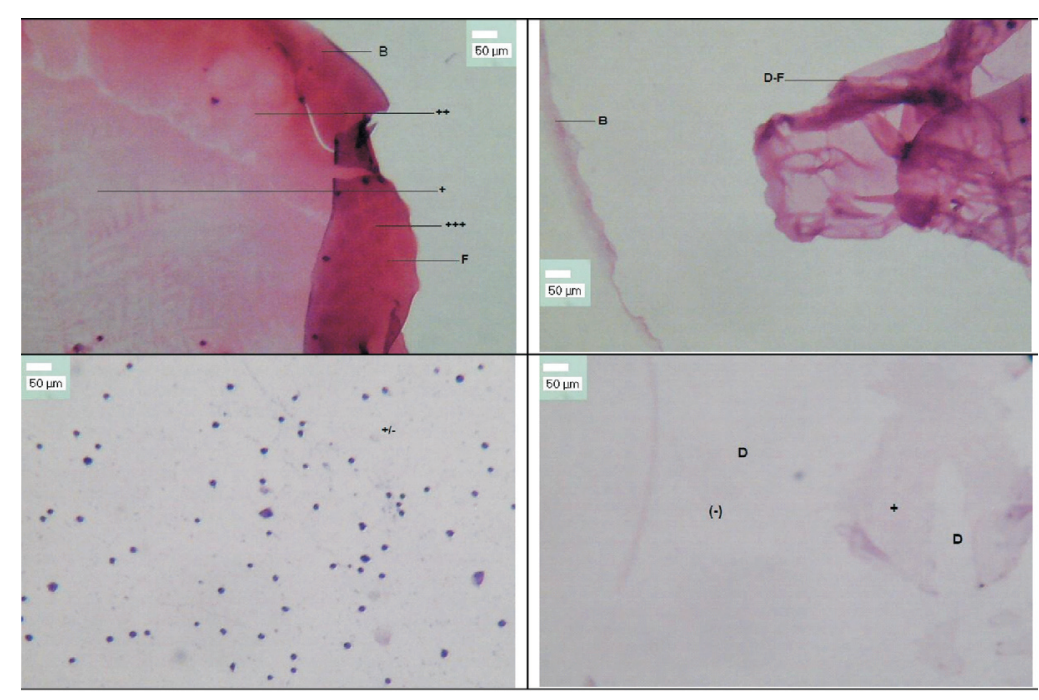

Figure 1. Background and boundary color assessment

$\mathrm{B}=$ boundary, $\mathrm{F}=$ folded, $\mathrm{D}=$ detached, $\mathrm{D}-\mathrm{F}=$ detached and folded, $(-)=$ clear, $\pm=$ clear with some pale dots, $+=$ pale,$++=$ lightly colored, $+++=$ colored

Table 1. Backgrounds and images of the six approaches

\begin{tabular}{|c|c|c|c|c|c|}
\hline & Background color & Boundary intactness & Boundary color & Folded partsOP & Detached parts \\
\hline Approach 1-1 & + & +++ & ++ & $(-)$ & $(-)$ \\
\hline-2 & + & ++ & ++ & $(-)$ & $(-)$ \\
\hline-3 & + & +++ & ++ & $(-)$ & $(-)$ \\
\hline-4 & + & ++ & ++ & $(-)$ & $(-)$ \\
\hline-5 & \pm & +++ & +++ & $(-)$ & $(-)$ \\
\hline Approach 2-1 & $(-)$ & + & ++ & $(-)$ & NA \\
\hline-2 & $(-)$ & ++ & ++ & $(-)$ & NA \\
\hline-3 & $(-)$ & + & ++ & $(-)$ & NA \\
\hline-4 & $(-)$ & ++ & ++ & $(-)$ & NA \\
\hline-5 & $(-)$ & + & ++ & $(-)$ & NA \\
\hline Approach 3-1 & + & +++ & ++ & $(-)$ & + \\
\hline-2 & + & +++ & ++ & + & ++ \\
\hline-3 & + & ++ & ++ & $(-)$ & ++ \\
\hline-4 & + & +++ & ++ & + & ++ \\
\hline-5 & ++ & +++ & +++ & + & $(-)$ \\
\hline Approach 4-1 & \pm & +++ & ++ & $(-)$ & + \\
\hline-2 & \pm & ++ & ++ & + & + \\
\hline-3 & \pm & $(-)$ & ++ & $(-)$ & NA \\
\hline-4 & \pm & +++ & ++ & $(-)$ & + \\
\hline-5 & \pm & +++ & +++ & $(-)$ & $(-)$ \\
\hline Approach 5-1 & +-+++ & +++ & ++ & ++ & NA \\
\hline-2 & +-+++ & +++ & ++ & +++ & NA \\
\hline-3 & $(-)- \pm$ & +++ & ++ & $(-)$ & +++ \\
\hline-4 & $(-)- \pm$ & +++ & ++ & $(-)$ & +++ \\
\hline-5 & $(-)-++$ & +++ & +++ & $(-)$ & $(-)$ \\
\hline Approach 6-1 & ++ & +++ & +++ & + & + \\
\hline-2 & ++ & +++ & +++ & + & + \\
\hline-3 & + & +++ & +++ & $(-)$ & + \\
\hline-4 & + & +++ & +++ & $(-)$ & + \\
\hline-5 & + & +++ & +++ & $(-)$ & + \\
\hline
\end{tabular}

$\mathrm{NA}=$ not applicable, background and boundary color: $(-)=$ very clear, $\pm=$ clear with some pale dots, $+=$ pale,$++=$ lightly colored, $+++=$ colored, background boundary: $(-)=$ not seen, $+=0-25 \%$ intact, $++=26-75 \%$ intact, $+++=>76 \%$ intact, folded parts: $(-)=$ not seen, $+=0-25 \%$ folded, $++=26-50 \%$ folded, $+++=>50 \%$ folded, detached parts: $(-)=$ not seen, $+=0-25 \%$ detached, $++=26-50 \%$ detached, $+++=>50 \%$ detached 
Table 2. The percentage of attached intact cells for each approach

\begin{tabular}{|c|c|c|c|c|c|c|}
\hline & \multicolumn{6}{|c|}{ Percentage of attached intact cells } \\
\hline & Appr -1 & Appr -2 & Appr -3 & Appr -4 & Appr -5 & Appr -6 \\
\hline Slide 1 & 42 & 69 & 94 & 31 & 35 & 117 \\
\hline Slide 2 & 40 & 44 & 46 & 27 & 58 & 73 \\
\hline Slide 3 & 63 & 63 & 15 & 60 & 4 & 25 \\
\hline Slide 4 & 44 & 52 & 23 & 71 & 8 & 27 \\
\hline Slide 5 & 70 & 63 & 66 & 85 & 73 & 39 \\
\hline Mean & 51.8 & 58.2 & 48.8 & 54.8 & 35.6 & 56.2 \\
\hline SD & 13.7 & 10.0 & 32.2 & 25.2 & 30.3 & 39.1 \\
\hline
\end{tabular}

Background evaluation (color and boundary), folded and detached parts for every slide was qualitatively evaluated, noted, and presented descriptively. Further, the number of cells in every cell suspension was noted. The number of cells spotted was calculated from the amount spotted and the number of cells in the suspension, and then noted. The number of attached intact cells on each glass slide was noted, and the percentage of attached intact cells from the amount of spotted cells was calculated.

\section{Data analysis and interpretation}

Statistical analysis was done using SPSS 13.0 for Windows. The means and standard deviations (SDs) of the percentage of each approach were calculated, and the differences between the six approaches were compared by ANOVA. Before ANOVA procedure was done, homogeneity and normality of the data were tested using Levene test and 1 sample Kolmogorov Smirnov test, respectively. Finally, the procedure with the highest percentage and most clear background, least folded and detached part was regarded as the best method.

\section{RESULTS}

In approach 1 and 2, the cell suspensions were spotted directly on to glass slides, without additional FBS. The FBS concentration in the two approaches was 5\% (10\% FBS in the medium was diluted by equal amount of trypsin). The final FBS concentration in both approach 3 and 4, and both approach 5 and 6 could be calculated and yielded around 20\% and 38\% FBS respectively.

The background image of the six approaches can be seen in table 1, and the percentage of attached intact cells, means and SDs for each approach can be seen in table 2. The data showed normal distribution and the variances were homogenous. The ANOVA result showed that there were no significant difference in the percentage of attached intact cells between the six approaches $(P=0.804)$.

Table 1 shows that additional FBS caused colored background. As clear background is preferred, additional FBS did not give good result in term of background color. In contrast, we preferred darker and intact boundaries when counting the cells, as sharp boundary helped to guide the examiner to what extent the slide should be moved. However, sometimes the boundaries were severely damaged (Table 1 ). Therefore counting took more time, as we had to move further than the boundary, and additional FBS did not give concluding result in term of boundary intactness. Moreover, table 1 shows that additional FBS tended to increase folded and detached part.

Table 2 shows that approaches using special glass slides i.e. approach-2 without additional FBS (final FBS concentration 5\%) followed by approach- 6 with the highest concentration of FBS showed the highest yield of attached intact cells, that were $58.2 \%$ and $56.2 \%$ respectively.

\section{DISCUSSION}

Addition of FBS (5-10\%) in cell suspension to be cytocentrifuged is recommended in making cytological specimens..$^{10}$ In order to preserve the cells and to get more intact cells, we used additional FBS (approach 3-6) to neutralize the trypsin.

In term of the background color, clear background is preferred. However, this study showed that additional 
FBS caused colored background. This result is in line with the recommendation to reduce protein content as excess protein may interfere with staining reaction. ${ }^{9}$ Further, as additional FBS tended to increase folded and detached part, but did not give concluding result in term of boundary intactness, additional FBS did not give any additional value to the quality of the specimens in term of background color, cell layer and boundary intactness, and prevention of cell layer folding.

In term of the amount of attached intact cells, additional FBS might count for the increase in intact cells, as FBS can neutralize the damaging effect of trypsin. Moreover, additional FBS might increase attached cells as it may serve as adhesive between the cells and glass slide, such as the use of albumin as glass slide coating. ${ }^{9}$ Although there was no significant difference between the 6 approaches, approach- 2 using special glass slides without additional FBS (final FBS concentration 5\%) showed the highest yield of attached intact cells (58.2\%) (Table 2). This result showed that 5\% FBS is enough to neutralize the damaging effect of trypsin, and to serve as adhesive.

In contrast, approach-5 that contained the highest FBS concentration using conventional glass slide yielded the lowest number of attached intact cells. This result may be due to the increase in detached part from the conventional glass slide due to excess FBS that negate the increase in the number of attached intact cells. However, approach-6 that also contained the highest FBS concentration as in approach-5 yielded the second highest number of attached intact cells. The reason is supposed to be due to the use of special glass slide in approach-6, as the special glass slide is claimed to be superior compared to conventional glass slide in term of cell attachment, which might play a role in the prevention of the detachment of the cell layer.

The limitation of this study was that counting was done by a single examiner, and the blinding method only worked for the 3 kinds of FBS final concentration, as the conventional and special glass slide was readily distinguishable.

This spot method is very simple and was proven to endure routine HE staining that uses dips in acid solution. To know whether the specimen can endure immunocytochemical staining that involves severe treatments without detachment of the cell layer, further study should be done.
If this simple method can endure immunocytochemical staining, it will be very valuable in stem cell research, as it can be used for the identification of the various kinds of stem cells and the calculation of the proportion of a certain kind of stem cell using 100-200 cells only.

In conclusion, we have developed a simple spot method for cultured cell suspension, and the best approach to make spot specimen is using special glass slide with $5 \%$ FBS in the cell suspension.

\section{Acknowledgment}

The authors would like to thank Mrs. Trimiatun for her technical assistance in preparing the samples, and Dr. Gentur Sudjatmiko spBP for facilitating the collection of adipose tissue specimens that were used to prepare the samples. This study was funded by DRPM UI, RUUI contract no 747B/DRPM-UI/A/N1.4/2009.

\section{REFERENCES}

1. Zuk PA, Zhu M, Ashjian P, De Ugarte DA, Huang JI, Mizuno H, et al. Human Adipose Tissue Is a Source of Multipotent Stem Cells. Molecular Biology of the Cell. 2002; 13: 4279-95

2. Zuk, PA, Zhu M, Mizuno H, Huang JI, Futrell WJ, Katz AJ, et al. Multilineage cells from human adipose tissue: implications for cell-based therapies. Tissue Eng.(2001; 7: 211-26.

3. Kern S, Eichler H, Stoeve J, Klüter H, Bieback K. Comparative Analysis of Mesenchymal Stem Cells from Bone Marrow, Umbilical Cord Blood, or Adipose Tissue. Stem Cells. 2006;24;1294-1301. Available from: http:// www.StemCells.com.

4. Jurgens WJFM, Oedayrajsingh-Varma MJ, Helder MN, Doulabi BZ, Schouten TE, Kuik DJ, et al. Effect of tissueharvesting site on yield of stem cells derived from adipose tissue: implications for cell-based therapies. Cell Tissue Res. 2008; 332:415-26.

5. Mitchel JB, Mc Intosh K, Zvonic S, Garret S, Floyd ZE, Kloster A, et al. Immunophenotype of human adiposederived cells: temporal changes in stromal-associated and stem cell-associated markers. Stem Cells. 2006;24:376-85

6. Oedayrajsingh-Varma MJ , van Ham SM, Knippenberg M, Helder MN, Klein-Nulend J, Schouten TE, et al. Adipose tissue-derived mesenchymal stem cell yield and growth characteristics are affected by the tissue-harvesting procedure. Cytotherapy. 2006; 8:166-77.

7. Kretlow JD, Jin YQ, Liu W, Zhang WJ, Hong TH, Zhou $\mathrm{G}$, et al. Donor age and cell passage affects differentiation potential ofmurine bone marrow-derived stem cells. BMC Cell Biology. 2008;9:60. Available from: http://www. biomedcentral.com/1471-2121/9/60. (13 pages).

8. Astori G, Vignati F, Bardelli S, Tubio M, Gola M, Albertini V, et al. In vitro and multicolor phenotypic characterization of 
cell subpopulations identified in fresh human adipose tissue stromal vascular fraction and in the derived mesenchymal stem cells. Journal of Translational Medicine. 2007;5:55. Available from: http:/www.translational-medicine.com/ content $/ 5 / 1 / 55.10$ pages.

9. Bales CE. Laboratory techniques. In: Koss LG. Koss' diagnostic cytology and its histopathologic bases. 5th edition. Vol.II. Philadelphia: Lippincott William and Wilkins; 2006. p. 1569-1634.

10. Orell SR, Sterrerr GF, Walters MNI, Whitaker D. The techniques of FNA cytology. In: Orell SR, Sterrerr GF, Walters MNI, Whitaker D. Manual and atlas of fine needle aspiration cytology. Hong Kong: Churchill Livingstone; 1986. p. 5-17. 